A Review of Policies and Treatments for Addiction to Hard Drugs: Saudi Arabia, the Netherlands, and Australia

\author{
Turky Hassan Abualola \\ Social Work Department \\ Umm Al Qura University, KSA
}

Mubarak Ali Rahamathulla Flinders University, Social Work Department Social science Faculty, Australia. 


\title{
A Review of Policies and Treatments for Addiction to Hard Drugs: Saudi Arabia, the Netherlands, and Australia
}

\author{
Turky Hassan Abualola
}

Social Work Department

Umm Al Qura University, KSA

\section{Mubarak Ali Rahamathulla}

\section{Flinders University, Social Work Department}

\section{Social science Faculty, Australia.}

Abstract. This article examines the policies currently applied in Saudi Arabia for treating people addicted to hard drugs. It places those policies in an international context by contrasting them with two countries with different approaches - The Netherlands and Australia. This review does not seek to identify which country has the 'best' treatments. Rather it examines the Saudi experience within a global context. The Netherlands is widely considered to be tolerant of drug use, and it has been innovative in its approaches to this issue. Australia is examined because it has adopted a 'middle' approach; it is neither as tolerant as The Netherlands nor as punitive as Saudi Arabia.

Key words: hard drugs, heroin, cocaine, methamphetamines, Saudi Arabia, drug policies, drug-abuse treatments.

\section{Introduction}

The aim of this paper is to review the policies and practices regarding treatments for addiction to hard drugs in Saudi Arabia (Kingdom of Saudi Arabia, KSA), and to contrast them to the approaches being applied in rather different jurisdictions - notably The Netherlands and Australia. This paper first traces the evolution of the Saudi system, and it then examines that system in the light of the methods used in The Netherlands and Australia. It concludes by considering the implications for practice in the Saudi hospital system.

Treatment for drug use is a major social and healthcare issue, and in this paper the focus is on hard drugs - such as heroin, cocaine, and methamphetamines - which are highly addictive and very difficult to treat. Much has been written on these subjects, and the literature is in constant flux as new approaches are trialled and refined. At present, there is a range of policies and approaches in use in different countries (Gahlinger, 2004; Hanson, Venturelli, \& Fleckenstein 2009; Harrison, Backenheimer, \& Inciardi 1996; Hart, Ksir, \& Ray 2008; Inciardi, 
2004). At one extreme are those nations that have adopted policies of firm repression and 'zero tolerance'. At the other extreme are societies that have adopted relatively tolerant policies, permitting some personal use of soft drugs while punishing the manufacture and trafficking of hard drugs. The focus of this article is the changes in policies and practices that have taken place in Saudi Arabia in recent decades. The policies and practices of The Netherlands and Australia provide useful points of contrast for this project; The Netherlands because its policy makers and medical researchers have energetically explored new approaches to dealing with this issue; Australia because it has adopted a 'middle' approach, being neither as tolerant as The Netherlands nor as punitive as Saudi Arabia.

Saudi Arabia's approach to treating people addicted to hard drugs has seen many significant changes in recent times. The main over-arching policy change was the move from zero tolerance to harm minimisation (Karoub, 2010). Saudi Arabia had long maintained a strict policy of zero tolerance for drug use and trafficking, but since the early 1990's the Government has gradually adopted the humane approach of harm minimization for both drug users and addicts though not for traffickers. The Saudi Committee for Combating Drugs has also developed programs to help drug users by means of treatment, rehabilitation, and monitoring (Stoicescu, 2012). Saudi Arabia has a number of citizens and guest workers who use hard drugs, the problem being exacerbated by the country's proximity to drug-producing regions such as Turkey and Yemen.

Drugs have featured in the Middle East since early recorded history. Some substances such as tobacco and qat (or gat, khat) were socially accepted and tolerated; indeed qat (a mild stimulant derived from a plant native to the Arabian Peninsula) and hashish have been used for millennia. It was in the early/mid-twentieth century that the government started to formally address the issue. At that time drug use was regarded as a sign of character weakness, a lack of piety, and an expression of criminal behaviour, and so it was deemed illegal, the courts being considered the places best suited to handle the problem (Al-Ankary, 1993, p. 25). In the early 1970's, cabinet issued new lists of proscribed substances and the penalties for the manufacture and sale of drugs of all types. At that time there was no national policy or formal program for the treatment of addiction; indeed, most clinical treatment regimens were piecemeal and merely copied some of the 
approaches being applied in other developed countries. According to a Ministry of Health report (1997), at that time Saudi Arabia still lacked sufficient staff trained in addiction-treatment (P. 15).

Al-Ankary (1993) stated that in the late 1970's, and particularly the 1980's, some important policy changes were made, the main change being that drug use became accepted as a socio-medical problem rather than a legal matter (P. 25). As evidence of this the Saudi Ministry of the Interior announced that all drug users and addicts who expressed the desire to become drug-free would be provided with medical assistance and would not face criminal charges (Abdel-Mawgoud, Fateem, \& Al-Sharif, 1995, pp. 369-376).

Viewing addiction to hard drugs as a socio-medical issue was not merely a minor adjustment; rather it was a highly significant and far-reaching development. It represented a change in thinking, the adoption of a new philosophy, the recognition that the former approach was no longer appropriate and that another approach might yield better outcomes, and it led to the implementation of radical changes in clinical practices. (Abdel-Mawgoud, et al. 1995, pp. 369376) argue that such a major shift between 1986 and 1995 resulted in a revolution in rehabilitation programs. They explained that the philosophical foundation for treatment was adapted from the CENAPS bio-psycho-social model developed in the US by the Centre for Applied Science; this model requires patients to agree to a 30-day treatment contract (Marlatt \& Donovan, 2005). In making such changes Saudi Arabia was not acting in isolation: the country is a signatory to most international conventions relevant to welfare, drug control, and allied matters, and these various obligations entail the government meeting international standards set by the UN, WHO, and other international agencies.

Until 1986 drug treatments in Saudi Arabia were administered in general hospitals or psychiatric facilities, but in that year the first of four specialist drug-treatment clinics (named Al Amal hospitals) was opened. It is not evident from public documents why the government took so long to provide such clinics; however, it appears that by the mid-1980's the nation had acquired adequate financial resources to devote to a range of specialist, high-intensity, healthcare centres. It is possible, too, that policy makers were uncertain about the forms of treatment that should be provided. Evidence of this is apparent in the work of Abdel-Mawgoud, et al. (1995) who described marked 
fluctuations in the rehabilitation programs that were used between 1986 and 1995 ( Pp. 369-376). However, since 1995 the clinics have provided consistent forms of comprehensive treatment based on clear philosophies and structured programs. To the best knowledge of the researchers Saudi Arabia is yet to critically review the outcomes of its policy changes and new treatment methods offered in the Al Amal hospitals. It is timely that Saudi Arabia's new hard drug policies are reviewed and compared with other countries, which will help policy makers in Saudi Arabia to understand their own policy position and the ways in which Saudi policies could be improved. Keeping this in view the present research aims to review Saudi Arabia's hard drug policies in the light of those of The Netherlands and Australia.

\section{Methodology}

The data regarding drug-treatment policies and practices in both Australia and The Netherlands were obtained from secondary sources including government reports, hospital and medical records, official policy documents, and various drug-policy websites. Data pertaining to Saudi Arabia were collected through individual face-to-face interviews and through a focus group discussion attended by various practitioners from three hospitals namely Al Amal hospitals (the main drug-treatment centres) in Saudi Arabia. The hospitals are located in the cities of Jeddah, Riyadh and Dammam. In order to conduct the interviews and the focus group, the main researcher spent about one month in each of the three drug treatment centres. Purposive sampling was used to identify possible participants, with recommendations for likely contributors being provided by the respective directors of those hospitals. Invitations were sent by letters and emails to prospective participants in each hospital. Forty-three participants attended face-toface interviews, including 18 psychiatrists and 25 people who held positions within therapeutic teams; they included psychologists, social workers, and other allied clinical professions.

The research questions used in the interviews required detailed understanding of the subject and so it was important to obtain the views of those with current knowledge of drug policies and practices. A focus group was convened at the Al Amal hospital in Jeddah, the participants consisting of two social workers, one recovery consultant, one mental-health consultant, one consultant psychologist, one consultant occupational therapy, and one religious consultant. The researcher used both structured and semi-structured questions, the 
discussion focusing on four main areas: epidemiology of drug use; hard-drug addiction treatment policies; hard-drug addiction treatment practices; and hard-drug addiction rehabilitation practices. The discussion was recorded for later analysis.

Thematic analysis (Greg, Kathleen \& Emily 2012) was used to analyse the qualitative data and to identify themes. Axial coding (Strauss, 1987) was used to organize the themes into categories and the final form of each theme was constructed after completion of the coding. The researcher used all of the strategies recommended by Merriam (2009) to ensure the reliability, ethical standards, and trustworthiness of the project (P. 23).

These data from Saudi Arabia were supplemented by information from a wide range of secondary sources of drug-addiction literature including research reports, policy statements, and drug treatment documentation. An impediment to this investigation stemmed from the lack of detailed data regarding treatment outcomes. Since privacy and confidentiality are of great importance in Saudi Arabia, all of the official documents are general in nature and do not provide specific, quantitative details about treatment regimens or their results. They provide general descriptions of the roles and responsibilities of the agencies, but the policies are rather nonspecific.

\section{Results}

It is repeated here that the purpose of this study was not to rank countries in terms of the standards or efficacy of their treatments (indeed, it is not possible anywhere to be definitive about which treatments are the most effective in achieving full abstinence or reduced drug use). Rather it was intended to show the range of treatment options and the changes that have taken place in recent decades in the three countries in this study. Table 1 provides an overview of the current policies and practices in Saudi Arabia, The Netherlands, and Australia. The table outlines the history of drug policies and practices, the influences of culture, community attitudes, geographical location, substance availability, treatments, and law enforcement. 


\section{Table 1: Comparative summary of the policies and practices} for the treatment of people addicted to hard drugs.

\begin{tabular}{|c|c|c|c|}
\hline & KSA & Netherlands & Australia \\
\hline $\begin{array}{l}\text { History of } \\
\text { drug } \\
\text { treatment } \\
\text { and response } \\
\text { of } \\
\text { governments } \\
\text { to hard-drug } \\
\text { abuse }\end{array}$ & $\begin{array}{l}\text { The first Al Amal } \\
\text { hospital was opened in } \\
1986 \text { in Dammam } \\
\text { followed by dedicated } \\
\text { hospitals for addiction } \\
\text { treatment in the cities } \\
\text { of Riyadh and Jeddah. }\end{array}$ & $\begin{array}{l}\text { - The Dutch drug policy was } \\
\text { announced in 1976. It called } \\
\text { for an integrated approach } \\
\text { between drug supply, } \\
\text { prevention, treatment, and } \\
\text { harm reduction, its aim } \\
\text { being to balance the } \\
\text { maintenance of public } \\
\text { health, public order, and } \\
\text { compliance with } \\
\text { international law. } \\
\text {-The Netherlands has } \\
\text { developed open-door health } \\
\text { centres and needle exchange } \\
\text { programs for hard-drug } \\
\text { users. The first needle } \\
\text { exchange program was } \\
\text { developed in Amsterdam in } \\
\text { 1984. } \\
\text { - There are approximately } \\
150 \text { needle/syringe } \\
\text { exchange centres in The } \\
\text { Netherlands. In } 2012 \text {, there } \\
\text { were } 740 \text { treatment places } \\
\text { for medical heroin } \\
\text { prescriptions in } \\
\text { municipalities. } \\
\text { - Addiction care is offered } \\
\text { by specialized organizations } \\
\text { at some } 200 \text { locations } \\
\text { throughout the country. }\end{array}$ & $\begin{array}{l}\text { - Methadone-maintenance was } \\
\text { endorsed as an effective } \\
\text { treatment for opioid } \\
\text { dependence in 1985, and } \\
\text { buprenorphine has been used } \\
\text { for the same purpose since } \\
2000 \text {. } \\
\text { - The first Australian needle- } \\
\text { and-syringe program (NSP) } \\
\text { began in Sydney in 1986. By } \\
\text { 1988, a NSP system had been } \\
\text { implemented across Australia. } \\
\text { There are more than 3,000 } \\
\text { NSP outlets in Australia } \\
\text { located in a range of settings } \\
\text { including hospitals, } \\
\text { pharmacies, community health } \\
\text { centres, and drug treatment } \\
\text { agencies. }\end{array}$ \\
\hline $\begin{array}{l}\text { Role } \\
\text { religion }\end{array}$ & $\begin{array}{l}\text { Religion is at the core } \\
\text { of Arab culture and } \\
\text { identity, and this is } \\
\text { particularly so in KSA, } \\
\text { which considers itself } \\
\text { the centre of Islam. } \\
\text { Religious beliefs are } \\
\text { an important context in } \\
\text { which problems, } \\
\text { including medical and } \\
\text { health problems, are } \\
\text { constructed and } \\
\text { resolved. Religion has } \\
\text { strong influence in } \\
\text { policy making and } \\
\text { treatment programs. }\end{array}$ & $\begin{array}{l}\text { Religious diversity is a } \\
\text { feature of The Netherlands. } \\
\text { Religion has little influence } \\
\text { on drug treatments or drug } \\
\text { policies. }\end{array}$ & $\begin{array}{l}\text { Religion is rarely used in } \\
\text { shaping medical policies in } \\
\text { Western countries such as } \\
\text { Australia. }\end{array}$ \\
\hline $\begin{array}{l}\text { Role } \\
\text { culture }\end{array}$ & $\begin{array}{l}\text { Since the use of } \\
\text { alcohol and drugs is } \\
\text { illegal in KSA, those } \\
\text { who abuse them are } \\
\text { burdened with stigma } \\
\text { and limited treatment } \\
\text { options. }\end{array}$ & $\begin{array}{l}\text { - 'Normalization' and social } \\
\text { tolerance of drug abuse are } \\
\text { key elements in Dutch } \\
\text { policy. } \\
\text { - Dutch culture was built on } \\
\text { two layers: The under-layers } \\
\text { were formed by different }\end{array}$ & $\begin{array}{l}\text { - Society looks at soft-drug } \\
\text { use as a personal health } \\
\text { issue. However, the } \\
\text { society's perspective of drug } \\
\text { addiction is that it is } \\
\text { considered to be a mental } \\
\text { health issue that needs }\end{array}$ \\
\hline
\end{tabular}




\section{Egyptian Journal of Social Work (EJSW) http://ejsw.journals.ekb.eg Print ISSN: 2356-9204 Online ISSN: 2356-9212 Vol 3, Issue 1, January 2017}

\begin{tabular}{|c|c|c|c|}
\hline & KSA & Netherlands & Australia \\
\hline & $\begin{array}{l}\text { - Culture and traditions } \\
\text { are central parts of } \\
\text { Arab life, though qat } \\
\text { has been used in the } \\
\text { region for millennia. }\end{array}$ & $\begin{array}{l}\text { subcultures and their } \\
\text { structure was a combination } \\
\text { of social } \\
\text { characteristics } \\
\text { movements of philosophies } \\
\text { of life. The upper-layer has } \\
\text { limited control over the life } \\
\text { of Dutch society and it } \\
\text { contains a system of rules } \\
\text { focussed on common } \\
\text { interest. }\end{array}$ & $\begin{array}{l}\text { treatment. } \\
\text { The Australian government } \\
\text { retains a policy of } \\
\text { multiculturalism but this has } \\
\text { meant that it has to take } \\
\text { account of the views of } \\
\text { those from different } \\
\text { backgrounds. }\end{array}$ \\
\hline $\begin{array}{l}\text { Community } \\
\text { attitudes }\end{array}$ & $\begin{array}{l}\text { Drug use was } \\
\text { formerly regarded as } \\
\text { an indication of } \\
\text { personal weakness and } \\
\text { as a lack of religious } \\
\text { belief, but now it is } \\
\text { more accepted as a } \\
\text { health issue that } \\
\text { should be addressed by } \\
\text { medical intervention } \\
\text { and behavioural } \\
\text { change. }\end{array}$ & $\begin{array}{l}\text { - Policies and practices } \\
\text { regarding drug use and } \\
\text { treatments in } \\
\text { Netherlands have been } \\
\text { determined less by public } \\
\text { opinion, ideologies, and } \\
\text { economics, and more by } \\
\text { pragmatism, which is } \\
\text { designed to test the } \\
\text { effectiveness of intervention } \\
\text { through clinical practice. }\end{array}$ & $\begin{array}{l}\text { - During the } 1980 \text { s and } 1990 \mathrm{~s} \\
\text { attitudes changed in respect to } \\
\text { the use of 'softer' drugs such } \\
\text { as marijuana, but not for hard } \\
\text { drugs. Also, it was becoming } \\
\text { apparent that (to some extent } \\
\text { at least) the community } \\
\text { recognized that drug use had a } \\
\text { personal and social dimension; } \\
\text { that is, people sometimes } \\
\text { turned to drug use as a way of } \\
\text { dealing with personal and } \\
\text { emotional problems. }\end{array}$ \\
\hline $\begin{array}{l}\text { Geographic } \\
\text { location }\end{array}$ & $\begin{array}{l}\text { - Saudi Arabia is near } \\
\text { several countries } \\
\text { which are sources of } \\
\text { various hard drugs; in } \\
\text { particular Afghanistan, } \\
\text { Yemen, Pakistan, } \\
\text { Syria and Turkey. } \\
\text { - It has porous land } \\
\text { borders and a steady } \\
\text { influx of migrant } \\
\text { workers from poor } \\
\text { opium-producing } \\
\text { regions such Yemen } \\
\text { and Pakistan. }\end{array}$ & $\begin{array}{l}\text {-Netherlands is surrounded } \\
\text { by many European } \\
\text { countries. It is the recipient } \\
\text { of raw materials for hard } \\
\text { drugs, and being one of the } \\
\text { main transit cities for world } \\
\text { trade the port of Rotterdam } \\
\text { is particularly vulnerable to } \\
\text { drug importation by way of } \\
\text { shipping. }\end{array}$ & $\begin{array}{l}\text { - Australia has the advantage } \\
\text { of having no overland borders, } \\
\text { but it has been unable to } \\
\text { intercept drugs being secreted } \\
\text { in ever-more sophisticated } \\
\text { ways. } \\
\text { - Drug trafficking is caused by } \\
\text { refugees and immigrants from } \\
\text { many countries, and most } \\
\text { illegal imports come via south } \\
\text { Asian countries. }\end{array}$ \\
\hline $\begin{array}{l}\text { Substance } \\
\text { availability } \\
\text { in the } \\
\text { market }\end{array}$ & 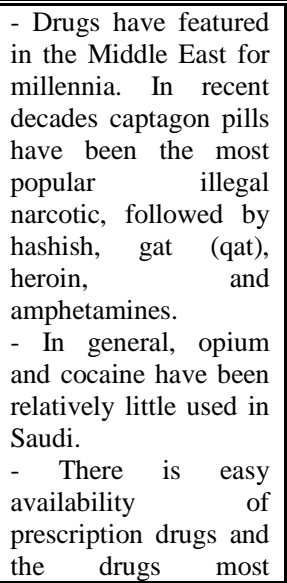 & $\begin{array}{l}\text { This country has the image } \\
\text { of a place where cannabis } \\
\text { has been readily available } \\
\text { and where it can be used } \\
\text { without fear of prosecution. } \\
\text { However, the current } \\
\text { situation is characterized by } \\
\text { growing availability of } \\
\text { drugs other than cannabis, } \\
\text { including hard drugs such as } \\
\text { heroin, methamphetamine, } \\
\text { ecstasy, and cocaine. } \\
\text { - The availability of drugs } \\
\text { was further supplemented } \\
\text { by its low price when } \\
\text { compared with the other } \\
\text { European countries; its } \\
\text { cheapness turned heroin into }\end{array}$ & $\begin{array}{l}\text { - Heroin and other opioids are } \\
\text { the main cause of drug-related } \\
\text { hospitalizations and represent } \\
\text { more than half of all drug- } \\
\text { related admissions in } \\
\text { Australia. } \\
\text { - The cultivation of cannabis } \\
\text { plants and the trafficking of } \\
\text { cannabis is illegal. However, } \\
\text { legislation to control cannabis } \\
\text { use is different from state to } \\
\text { state in Australia. } \\
\text { - In } 2013 \text { New South Wales } \\
\text { recommended the use of } \\
\text { medically-prescribed cannabis } \\
\text { for terminally ill patients and } \\
\text { has supported the legalization } \\
\text { of cannabis-based }\end{array}$ \\
\hline
\end{tabular}




\section{Egyptian Journal of Social Work (EJSW) \\ http://ejsw.journals.ekb.eg \\ Print ISSN: 2356-9204 Online ISSN: 2356-9212 Vol 3, Issue 1, January 2017}

\begin{tabular}{|c|c|c|c|}
\hline & KSA & $\begin{array}{c}\text { Netherlands } \\
\end{array}$ & Australia \\
\hline & $\begin{array}{l}\text { commonly used are } \\
\text { analgesics, and } \\
\text { psychotropic drugs. } \\
\text { - The United Nations } \\
\text { Office on Drugs and } \\
\text { Crime states that } \\
\text { amphetamine use has } \\
\text { risen sharply in KSA, } \\
\text { which accounted for } \\
28 \text { per cent of all } \\
\text { global amphetamine } \\
\text { seizures in } 2006 \text {. }\end{array}$ & $\begin{array}{l}\text { the drug of the poor. } \\
\text {-Since } 1976 \text { The } \\
\text { Netherlands has permitted } \\
\text { approved coffee shops to } \\
\text { offer marijuana to } \\
\text { customers, thus marking the } \\
\text { de facto legalization of } \\
\text { cannabis use in the country. }\end{array}$ & $\begin{array}{l}\text { pharmaceuticals on such } \\
\text { grounds. Patients are allowed } \\
\text { to possess up to } 15 \text { grams of } \\
\text { cannabis. }\end{array}$ \\
\hline $\begin{array}{l}\text { Current drug } \\
\text { policies }\end{array}$ & $\begin{array}{l}\text { Zero Tolerance / } \\
\text { Harm } \\
\text { Minimization } \\
\text { - A major change in } \\
\text { government policy was } \\
\text { the shift to harm } \\
\text { minimization, drug-use } \\
\text { and addiction now } \\
\text { being viewed as health } \\
\text { issues and not a } \\
\text { criminal matter. Death } \\
\text { penalty continues to be } \\
\text { applied for drug } \\
\text { trafficking. }\end{array}$ & $\begin{array}{l}\text { Harm Minimization / } \\
\text { Normalization } \\
\text { - Aim is to reduce adverse } \\
\text { consequences to the } \\
\text { individual and society in } \\
\text { order to help addicts return } \\
\text { to a normal, functioning } \\
\text { life. } \\
\text { - Drug trafficking is } \\
\text { punishable by long periods } \\
\text { of imprisonment. } \\
\text { - Drug interventions are } \\
\text { considered more important } \\
\text { than punishment, the } \\
\text { emphasis being on helping } \\
\text { users and addicts regain } \\
\text { health and normal } \\
\text { functioning. }\end{array}$ & $\begin{array}{l}\text { Harm Reduction } \\
\text { /Normalization } \\
\text { - Policies aim to reduce the } \\
\text { adverse health, social, and } \\
\text { economic consequences of } \\
\text { drug abuse. } \\
\text { - Imprisonment applies for } \\
\text { drug trafficking. . }\end{array}$ \\
\hline $\begin{array}{l}\text { Practice: } \\
\text { Professional } \\
\text { interventions } \\
\text { in use }\end{array}$ & $\begin{array}{l}\text { Pharmacotherapy } \\
\text { - Methadone has } \\
\text { been used in the } \\
\text { past but was } \\
\text { considered of } \\
\text { limited benefit, } \\
\text { - Naltrexone is } \\
\text { currently available } \\
\text { for use. } \\
\text { Other therapies } \\
\text { used to treat } \\
\text { people with drug } \\
\text { addiction } \\
\text { - Various to } \\
\text { approaches } \\
\text { facilitating changes } \\
\text { in behaviour, } \\
\text { attitudes, and } \\
\text { beliefs are applied. } \\
\text { - Bio-psycho-social } \\
\text { models are applied. } \\
\text { - Religion has strong } \\
\text { influence in policy- } \\
\text { making and } \\
\text { treatment }\end{array}$ & $\begin{array}{l}\text { Pharmacotherapy } \\
\text { - Methadone and } \\
\text { buprenorphine- } \\
\text { maintenance programs } \\
\text { are the most recent } \\
\text { pharmacotherapy } \\
\text { practices in use. } \\
\text { - Naltrexone is used on } \\
\text { occasion for reducing } \\
\text { cravings. } \\
\text { Other therapies used to } \\
\text { treat people with drug } \\
\text { addiction to } \\
\text { - In addition } \\
\text { behavioural therapies, } \\
\text { The Netherlands has } \\
\text { moved to a multi- } \\
\text { optional approach } \\
\text { where drug users can } \\
\text { choose from a variety } \\
\text { of treatment solutions, } \\
\text { e.g. methadone- } \\
\text { maintenance programs, } \\
\text { and psycho-social } \\
\text { treatment solutions. }\end{array}$ & $\begin{array}{l}\text { Pharmacotherapy } \\
\text { - Methadone } \\
\text { buprenorphine- } \\
\text { maintenance programs are } \\
\text { currently practiced. } \\
\text { - Naltrexone has been used } \\
\text { successfully in Australia } \\
\text { for a number of years as } \\
\text { part of a long-term } \\
\text { protocol for treating opiate } \\
\text { addiction. } \\
\text { Other therapies used to } \\
\text { treat people with drug } \\
\text { addiction in } \\
\text { - Psychotherapy } \\
\text { Australia consists } \\
\text { primarily of a bio-psycho- } \\
\text { social model. } \\
\text { Considerable use is made } \\
\text { of psychological therapy } \\
\text { programs and other } \\
\text { inclusive social activities } \\
\text { which assist addicts to re- } \\
\text { establish normal social } \\
\text { interactions. }\end{array}$ \\
\hline
\end{tabular}




\section{Egyptian Journal of Social Work (EJSW) \\ http://ejsw.journals.ekb.eg \\ Print ISSN: 2356-9204 Online ISSN: 2356-9212 Vol 3, Issue 1, January 2017}

\begin{tabular}{|c|c|c|c|}
\hline & KSA & Netherlands & Australia \\
\hline & $\begin{array}{l}\text { programs. } \\
\text { - There is more } \\
\text { dependence on } \\
\text { psychotherapies } \\
\text { influenced by } \\
\text { religion and } \\
\text { behaviour } \\
\text { modification. } \\
\text { Social therapies } \\
\text { - Arab clients tend to } \\
\text { be considered within } \\
\text { the context of the } \\
\text { family, extended } \\
\text { family, community, or } \\
\text { tribal background. } \\
\text { Interpersonal } \\
\text { contact between } \\
\text { patients and } \\
\text { medical services } \\
\text { - It is more important } \\
\text { to build a relationship } \\
\text { than to solve a } \\
\text { problem, and } \\
\text { relationships are built } \\
\text { through the Arab } \\
\text { notion of trust. It } \\
\text { involves family and } \\
\text { friends. }\end{array}$ & $\begin{array}{l}\text { Social therapies } \\
\text { - Western therapies are } \\
\text { an extension of the } \\
\text { development } \\
\text { individualism. } \\
\text { Interpersonal contact } \\
\text { between patients and } \\
\text { medical services } \\
\text { - Family and friends are } \\
\text { less involved in the } \\
\text { treatments and } \\
\text { interventions. }\end{array}$ & $\begin{array}{l}\text { Social therapies } \\
\text { - Western therapies are an } \\
\text { extension of the } \\
\text { development } \\
\text { individualism. } \\
\text { Interpersonal } \\
\text { between patients and } \\
\text { medical services } \\
\text { - Family involvement is } \\
\text { encouraged though not to } \\
\text { the exclusion of the work } \\
\text { of practitioners. }\end{array}$ \\
\hline $\begin{array}{l}\text { Government } \\
\text { policies: } \\
\text { attitudes of } \\
\text { policy- } \\
\text { makers }\end{array}$ & $\begin{array}{l}\text { - Attitudes by policy } \\
\text { makers have changed } \\
\text { slightly so there is } \\
\text { more acceptance of } \\
\text { drug-use as a personal } \\
\text { health issue (and a } \\
\text { mental-health } \\
\text { problem) and not as } \\
\text { criminal behaviour. } \\
\text {-There is tacit } \\
\text { acknowledgement that } \\
\text { drug-use has a long } \\
\text { history in the region as } \\
\text { shown by the } \\
\text { traditional use of qat } \\
\text { (Collins 2014). }\end{array}$ & $\begin{array}{l}\text { - The Netherlands has a } \\
\text { history of drug use, drugs } \\
\text { being imported mainly by } \\
\text { immigrants from some of } \\
\text { the former Dutch colonies. } \\
\text { - It also has a long history of } \\
\text { social tolerance. The } \\
\text { reputation for tolerance of } \\
\text { drug-use really only applies } \\
\text { to marijuana. } \\
\text { - Hard-drug use is } \\
\text { considered as a mental } \\
\text { health issue which needs } \\
\text { treatment (EMCDDA, } \\
\text { 2012). }\end{array}$ & $\begin{array}{l}\text { - Official government policies } \\
\text { have moved from zero } \\
\text { tolerance to } \\
\text { minimization. } \\
\text { - Drug addiction is often } \\
\text { associated with mental illness } \\
\text { and so should be treated as a } \\
\text { medical issue and not as } \\
\text { criminal behaviour. }\end{array}$ \\
\hline $\begin{array}{l}\text { Law } \\
\text { enforcement }\end{array}$ & $\begin{array}{l}\text { - Death penalties for } \\
\text { drug manufacture } \\
\text { and trafficking. } \\
\text { - The government is } \\
\text { allocating more } \\
\text { funds for programs } \\
\text { to discourage } \\
\text { individuals from } \\
\text { turning to drugs. } \\
\text { (Abdel-Mawgoud, } \\
\text { et al. 1995: } \\
\text { Karoub, 2010) }\end{array}$ & $\begin{array}{l}\text { - Normalization' is a } \\
\text { pragmatic position between } \\
\text { legislation and the war on } \\
\text { drugs. This is new to the } \\
\text { operations instituted by this } \\
\text { nation. It gives soft options } \\
\text { for the addict regarding } \\
\text { social, cultural, and } \\
\text { economic needs. This is a } \\
\text { liberal practice to eliminate } \\
\text { labelling and stigmatization. } \\
\text { (European Monitoring }\end{array}$ & $\begin{array}{l}\text { - Law enforcement has } \\
\text { remained fairly constant for } \\
\text { decades. Dealing with hard } \\
\text { drugs usually results in } \\
\text { imprisonment, although the } \\
\text { penalty depends on quantity } \\
\text { and nature of the particular } \\
\text { drug. Pharmaceuticals and } \\
\text { hard drugs incur more severe } \\
\text { penalties. } \\
\text { - Law enforcement focuses on } \\
\text { the importation of drugs and }\end{array}$ \\
\hline
\end{tabular}




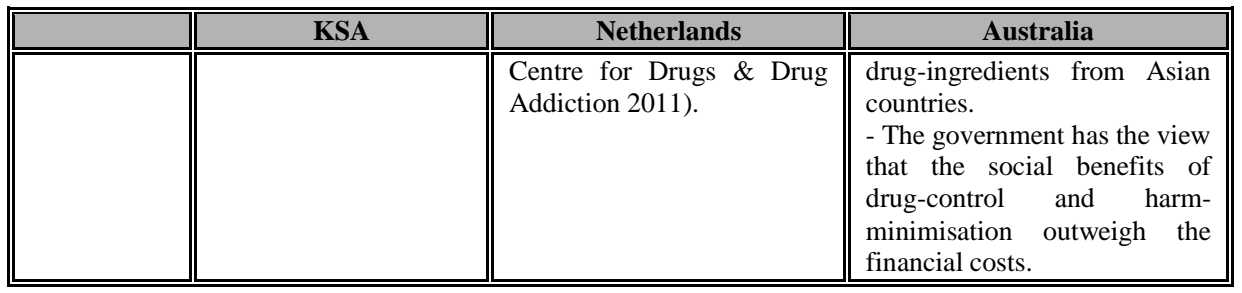

\section{Discussion}

\section{Current Policies and Practices}

It can be seen from the table above that while there are some fundamental similarities, the governments and healthcare authorities in the three countries have adopted some noticeably different approaches.

\section{History of Drug Treatments and Government Responses to Hard-Drug Use}

Drug problems have a long history in each of the three countries, and each country has developed its own responses. But it was in the 1960's and 1970's that the use of hard drugs emerged as a major global issue. Al Mutairi (1996) stated that in KSA, the first closely-documented case of the use of hard drugs and the clinical treatment of the addict was reported in the professional literature in 1965 (P. 43). However, the Saudi Government took a further 20 years to realise the need to provide medical treatment for addicts. In 1986, KSA opened its first drug treatment centre, Al Amal Hospital, in Dammam, a city on the east coast. (Royal Order No. 2108 of 06/11/1982). The long delay in establishing dedicated facilities for addiction treatment may have been due to the fact that Saudi society was quite under-developed and isolated before the development of the oil fields. Also, at that time the drug problem was deemed very small, and there were many other pressing priorities (Al Mutairi, 1996, p. 44). Moreover, drug use was popularly viewed as a personal failing and not as a medical or health issue, and substitute programs and needle exchanges were considered to be culturally inappropriate for Saudi society.

In The Netherlands, community concern about the rapidly rising use of drugs of all types led to the formulation in 1976 of a clear policy statement. The policy included implementation of a range of steps to treat drug abuse (Schatz, Schiffer \& Kools 2011); the first needle-exchange program was launched in Amsterdam in 1984 (Marlatt, 2008), and this has expanded so that today the country has 
approximately 150 regional needle-exchange programs and 740 treatment places for heroin prescriptions in 18 different locations around the country (Van Laar, Cruts, Houben, Croes, Pol, Meijer \& Ketelaars 2014). The Netherlands' 'open-door' health centres offer addiction care at some 200 locations run by specialized organizations, and emergency housing is provided in some towns adjacent to the care facilities (European Monitoring Centre for Drugs \& Drug Addiction 2012 ).

In Australia, too, drug use was not recognised as a major issue in Australia until the 1960's and 1970's when the rates of addiction rose significantly (Darke, Ross, Zador, \& Sunjic, 2000; Statistics on Drug Use in Australia, 1994 \& Statistics on Drug Use in Australia, 2006). It took some time (and many public enquiries and governmental reviews) before a coherent policy was formulated. Initially it was assumed that drug-use could be suppressed by the adoption of zero tolerance and by stern measures, but by the late 1970 's it was clear that these were ineffective (Pennington, 1999). Consequently, there was a change in the 1980's, and harm reduction became the new paradigm. This has remained the central element of the nation's drug program (Lowinson, Ruiz, Pedro, Millman, \& Langrod 2005; National Drug Strategy 2010).

It is noted in various Australian policy documents that the main goal of harm reduction is to reduce drug-related harm rather than the use of drugs per se (though of course that is the ideal solution). Acknowledging that drug use could not be eliminated, Australia opened its first needle and syringe exchange program (Needle \& Syringe Program - NSP) in Darlinghurst, Sydney in 1986. By 1988 the NSP system had been implemented across Australia, and in 2002 there were more than 3,000 NSP outlets in a range of settings including hospitals, pharmacies, community health centres, and drug treatment agencies (Return on Investment in Needle and Syringe Programs in Australia, 2002, p. 9).

\section{Religious, Cultural, and Community Attitudes}

In KSA, social policies are shaped by the Islamic religion. This is also reflected in the nation's drug policies and approaches to treatment. While the country has moved towards accepting drug addiction as a medical and healthcare issue rather than a criminal matter, there is still a strong stigma associated with addiction to any substances. The issue has long been avoided and hidden by addicts 
and their families who have preferred not to address it in any meaningful way (Gallahue, 2012; Karoub, 2010). The insistence that all issues be assessed according to religious precepts also means that religion has been used to inhibit the use of such measures as pharmacotherapies, in particular the use of substitute drugs (Al Brithen, 2006, p. 13). While substitutes such as methadone and buprenorphine have been used from time to time, the Saudi system has instead placed greater reliance on methods such as psychiatric therapies, therapeutic communities, behaviour-modification techniques, and religious studies (Marlatt \& Donovan, 2005; Stoicescu, 2012).

The Netherlands has for centuries adopted the liberal-democratic philosophy that accords considerable freedom of choice to the individual, and this has been reflected in the attitude to drug-use, where there has been tolerance of individualistic behaviour. The Netherlands has been at the forefront of many developments concerning drug use and drug treatments, and it was an early proponent of the concept of harm minimization. This has remained a cornerstone of Dutch drug policies, and the ultimate goal of the Dutch system is to assist addicted individuals to re-establish themselves as normally-functioning individuals ( European Monitoring Centre for Drugs \& Drug Addiction 2011; Haasen, Verthein, \& Degkwitz, 2007; van Laar, 2012).

As a result of these policy shifts, the Dutch system has aimed to 'normalize' drug use (Marlatt, 2008). This is a pragmatic position between legalization and a 'war' on drugs, a position in which drug treatment policies aim to meet addicts' health and welfare needs (Wolf, Linssen, \& Graaf, 2003). Normalization also seeks to reduce all forms of harm that may result from strict control over drug use. Moreover, it can be considered the opposite of law enforcement and punishment because its objective is to eliminate stigmatization of addicts, and to separate them from drug markets (Wolf, et al., 2003). As noted above, the marketing of hard drugs is a criminal offence in The Netherlands, however addicts are treated with great compassion, and considerable resources are devoted to assisting them (Marlatt, 2008).

In general, Australia's harm reduction strategies assume that many people will continue to use drugs, and therefore the concern is to reduce or minimize any associated harms to both users and others in 
society (Lenton, Dietze, Degenhardt, Darke, \& Butler 2009). Treatment measures being applied in Australia include pharmacotherapies and psycho-social methods.

\section{Geographical Factors and the Availability of Drugs}

The geographical location of a country can influence the availability of hard drugs. In this respect, KSA is particularly vulnerable. It is situated near several sources of hard drugs, in particular Afghanistan, Yemen, Pakistan, Syria, and Turkey (United Nations Office on Drugs \& Crime, 2008, p. 59). Moreover, it has porous land borders and a steady influx of migrant workers from poor opium-producing regions.

The Netherlands has a long history as a country of transit, and this exposure to world trade (Rotterdam being the largest seaport in the world) continues to facilitate drug importation (Dolin, 2001).

Australia has the advantage of having no overland borders, but it too has been unable to intercept all drugs being smuggled by air, sea, and post in increasingly sophisticated ways.

\section{Current Drug Policies}

A comparison of public policies being applied in the three countries has indicated two broad policy approaches: zero tolerance of trafficking and distribution of drugs; and harm minimization for people who are addicted to hard drugs. While KSA has maintained a strict policy of zero tolerance for drug importation and trafficking, since the 1990's the Saudi government has adopted a more humane policy of harm minimization for drug users and addicts, and suitable treatment strategies and programs have been developed in the $\mathrm{Al}$ Amal hospitals (Stoicescu, 2012). Many treatment and rehabilitation programs implemented in KSA have been influenced by the experiences of Western countries in dealing with alcohol dependence (Karoub, 2010).

Australia and The Netherlands have both adopted harm minimization principles through intervention methods such as methadone/buprenorphine programs, needle exchanges, and the establishment of sterile injecting centres. KSA and Australia have implemented broadly similar treatment models that comprise a blend of bio-psycho-social features, and both have a focus on educational programs (National drug strategic framework, 2012, Karoub, 2010). The Netherlands has a unique and more multi-optional program wherein users can choose from a variety of treatment solutions. 
Normalization, as discussed earlier, is the objective in The Netherlands (Wolf, et al., 2003).

\section{Law Enforcement}

The production and distribution of hard drugs (and the ingredients for the production of hard drugs) is illegal in all three countries. Like all developed nations each devotes considerable resources to drug interdiction, and the manufacture and distribution of addictive drugs is invariably punishable by long terms of imprisonment (European Monitoring Centre for Drugs \& Drug Addiction 2011; Lowinson, et al., 2005). Perhaps the main difference between the three is that KSA still applies capital punishment for the most severe cases (Abdel-Mawgoud, et al., 1995 \& Karoub, 2010) whereas in The Netherlands and Australia the trafficking of large quantities of drugs results in lengthy terms of imprisonment of 12 years or more.

\section{Treatment Approaches}

In regard to treatments for addiction, Australia and The Netherlands rely quite strongly on less-addictive substitute pharmaceuticals such as methadone and buprenorphine programs (Van Laar, 2012, \& National Opioid Pharmacotherapy Statistics Annual Data, 2012). As noted, methadone has been used in the Saudi healthcare system but is usually regarded as offering limited advantages and is reported to result in low rates of abstinence (Henning, 2010 \& Karoub, 2010).

Many treatment and rehabilitation programs implemented in KSA are influenced by the experiences of Western countries in dealing with alcohol dependence - the work of Alcoholics Anonymous often being cited. However, treatments in KSA today rely more on psycho-social techniques, with a high reliance on the influence of religion and behaviour-based therapies (Karoub, 2010). Although both The Netherlands and Australia have adopted harm minimization principles and practices there have been some differences between their approaches. In contrast, treatment measures applied in Australia are not a matter of personal selection and (depending on the drug of addiction) entail both pharmacotherapies and psycho-social methods (National Drug Strategic Framework, 2012). 


\section{Conclusion}

In summary, drug use and drug addiction are global problems, but different countries have addressed the issue in different ways. In general, drug treatment policies have been determined historically by two approaches; harm minimization and zero tolerance. The interpretation and application of those approaches in dealing with drug abusers differ from country to country, however, policy makers and practitioners learn from each other and seek to adopt measures that meet their particular needs. For example, normalization has proved effective in both the Netherlands and Australia, and it may be effective in KSA where the social stigma of using drugs is still the main obstacle to family involvement in therapy - yet family support is an important feature of most treatment programs.

This discussion demonstrates that policies and practices for treating addictions in KSA, The Netherlands, and Australia have steadily evolved through processes of research and review. The economic, social, and personal costs of drug use have been very high. The end result is that all three countries now implement harm minimization policies, which aim to:

...minimize the adverse health, social and economic consequences of drug use, without necessarily ending such use for people who cannot be expected to stop their drug use immediately. The primary goal of this approach is a net reduction in drug-related harm rather than becoming drugfree overnight (Gardner, 2006).

Harm minimization policies are also an expression of compassion and concern for the addict, and a recognition that individuals turn to drugs as a way of dealing with fears, anxieties, personal problems, or as an escape from social pressures.

While the communities in all three nations accept drug abuse as inherently undesirable, policy makers and professionals can draw on medical advice, cultural influences, religious guidelines, and psychiatric leadership to improve drug treatment policies and practices while respecting the local culture. Globally, billions of dollars have been spent in the fight against drugs. However, it seems that the willingness of individuals to use drugs has not diminished and so the demand continues unabated. History shows that hard drugs are an inherent and lethal part of all societies. KSA has dealt with drug use for centuries, and Saudi history is now inclining towards Western 
notions of accepting it as inevitable and unstoppable. The governments must look to minimize both the social and economic damage by establishing clear guidelines and by providing resources with which to deal with the problem.

Based on the comparison of drug treatment policies and practices in The Netherlands, Australia, and KSA, it is not possible to state definitively whether the treatment regimens applied therein are better (or worse) than any others. Each has its merits and its disadvantages, but new approaches will certainly evolve in the future.

\section{Implications for Practice}

This review has not sought to identify a 'best' form of treatment. Rather it has examined the Saudi approach in the light of the systems being applied in The Netherlands and Australia. Both these latter have not made any major alterations to their respective treatment regimes in recent years, but they constantly seek, by research, to refine and improve their methods. Saudi Arabia is very cautious in it approaches, having a culture which is conservative and slow to change. Perhaps the main implication of this review is that practitioners in Saudi hospitals need to be constantly aware of developments in other countries, and willing to explore other options. For example, while substitute drugs (such as methadone) may not be an ideal solution, nevertheless they have been shown, in countries such as Australia and The Netherlands, to be effective in certain circumstances. Saudi practitioners need to be open to new and different methods, and this may mean advocating for change even if there is initial resistance to any new approaches.

\section{References}

Abdel-Mawgoud, M., Fateem, L. \& Al-Sharif, A.I. (1995). Development of a comprehensive treatment program for chemical dependency at Al Amal Hospital, Dammam. Journal of Substance Abuse Treatment, 12(5): 369-76.

Abosag, I., \& Lee. Joong woo (2013). The formation of trust and commitment in business relationships in the Middle East: Understanding Et-Moone relationships. International Business Review, 22(3): 602-614, June.

Ahmed, M. (2009). Drug-associated admissions to a district hospital in Saudi Arabia. Journal of Clinical Pharmacy and Therapeutics, 22(1): 61-6.

Al Brithen, A. (2006). Alcoholism and Domestic Violence in Saudi Society, University of Liverpool: 4, 7, 8, 16 .

Al Mutairi, F. (1996). Obstacles for addicts to gain treatment at an addiction centre, Naïf Arab Academy for Security Science: Al Riyadh: 29, 133-240.

Al Sakran, R. (2011). Drugs' target of 5 million students in the campaign, Wiqaiya. Retrieved from, http://www.wiqaiya.com/NewsDetail.aspx?ID=53. 
Al-Ankary, S. (1993). Addiction and the Effort of the KSA in Curing Addicted People, Saudi French seminar in the field of fighting drugs, 25 - 28 January 1994: Riyadh.

Al-Krenawi, A. \& Graham, J.R. (2000). Culturally Sensitive Social Work Practice with Arab Clients in Mental Health Settings. Publication of the National Association of Social Workers: Washington DC.

Alsanosy, R., Mahfouz, M.,\& Gaffer. A. (2013). Khat Chewing Habit among School Students of Jazan Region, Saudi Arabia, Naif Journal, viewed 2014, http://www.plosone.org/article/info\%3Adoi\%2F10.1371\%2Fjournal.pone.006 $\underline{5504}$.

Arab News (2010). Makkah region leads in drug abuse, retrieved from, http://www.arabnews.com/node/343709.

Arafa, H.O. (2011). The Program of Extended Care Unit, Retrieved from, http://daharchives.alhayat.com/issue_archive/Hayat\%20KSA/2008/1/19/\%D.

Australian Crime Commission (2009). Illicit Drug Data Report 2008-2009, Retrieved

from, http://www.crimecommission.gov.au/publications/iddr/_files/2008_09/04\%20Hero in\%200809.

Australian Institute of Health and Welfare (2006). Alcohol and other drug treatment services in Australia 2004-05. Drug Treatment Series No 5. AIHW, cat. No. HSE 43, Canberra, retrieved from, https://www.aihw.gov.au/WorkArea/DownloadAsset.aspx?id=6442456808

Becker, J. \& de Hart, J. (2006). Godsdienstige veranderingen in Nederland. Social and Cultural Planbureau.

Boekhout, G,. \& Van, S. T. (1998). Drug use and drug trafficking in Europe. Tijdschrift voor Economische en Sociale Geografie, 1: 100-105.

Boekhout, V. S. T. (1999). Dutch drug policy in a European context. Journal of Drug Issues, 29 (3): 511-28. Pre-publication version.

Boekhout, V.S.T. (2004). Dealing with Drugs in Europe. An Investigation of European Drug Control Experiences: France, the Netherlands \& Sweden. BJu Legal Publishers: The Hague.

Brink, V.D., Hendricks, V.M. \& Ree, J.M. (1999). Medical co-prescription of heroin to chronic, treatment-resistant methadone patients in the Netherlands. Journal of Drug Issues, 29(3): 587-608.

Collins, D., Lapsley, H. \& Marks, R. (2007). Illicit drugs damage Australian business. Australian Drug Law Reform Foundation: p.4.

Collins, C.,(2014) English Dictionary, HarperCollins. Retrieved from http://www.thefreedictionary.com/khat

Commonwealth Department of Health and Ageing (2002). Return on investment in needle \&syringe programs in Australia: Summary Report, Retrieved from http://www.ffdlr.org.au/campaigns/docs/ROI\%20on\%20NSP\%20Summary.pdf

Coultan, M. (2013). Medical-use marijuana backed", The Australian. Retrieved from http://www.theaustralian.com.au/national-affairs/state-politics/medical-usemarijuana-backed/story-e6frgczx-1226643417115. 
Darke, S., Ross, J., Zador, D. \& Sunjic, S. (2000). Heroin-related deaths in New South Wales, Australia, 1992-1996. Drug \& Alcohol Dependence, 60(2): 14150 .

Department of Immigration and Citizenship (2008). The People of New South Wales: Statistics from the 2006 Census. Commonwealth of Australia: Canberra.

Dolin, B. (2001). National Drug Policy: The Netherlands. Paper for the Senate Special Committee On Illegal Drugs, Law and Government Division, Library of Parliament, http://www.parl.gc.ca/content/sen/committee/371/ille/library/dolin1-e.htm

European Monitoring Centre for Drugs \& Drug Addiction (2011). Annual report 2011: the state of the drugs problem in Europe, retrieved from http://www.emcdda.europa.eu/online/annual-report/2011/amphetamines/3

European Monitoring Centre for Drugs \& Drug Addiction (2012). Annual report: the state of the drugs problem in Europe. European Monitoring Centre for Drugs and Drug Addiction, Lisbon. Summary for The Netherlands, retrieved from file:///C:/Users/turki/Downloads/TDAC12001ENC_\%20(2).pdf.

Gahlinger, P.M. (2004). Illegal Drugs. Plume ooks: New York.

Gallahue, P., Gunawan, R., Rahman, F., El Mufti, K., U Din, K. \& Felten, R. (2012). The Death Penalty for Drug Offences: Global Overview 2012. International Harm Reduction Association, 2012.

Galligan, B. \& Ravenhill, J. (1997). New Developments in Australian Politics. Macmillan Education AU: Sydney: 13.

Gardner, P. (2006). A Magnifying Glass over Harm Minimisation. New Zealand Centre for Political Research (Guest Forum), www.nzcpr.com/guest19.htm.

Gatto, C. (1999). European drug policy: Analysis \& case studies. Retrieved from, http://norml.org/component/zoo/category/european-drug-policy-analysis-and-case$\underline{\text { studies }}$

Gatto, C. (2002). European Drug Policy: 2002 Legislative Update. Retrieved from http://norml.org/library/item/european-drug-policy-2002-legislative-update

General Directorate for Drug Control (n.d.) Drugs dangers \& resistance, Press Public Security: Riyadh.

Government of Netherlands (2011). The Dutch Cabinet: Coffee shop to be a private club for the local market. Retreived from http://www.government.nl/documents-and-publications/pressreleases/2011/05/27/the-dutch-cabinet-coffeeshop-to-be-a-private-club-forthe-local-market.html.

Greg, G. Kathleen. M. M. \& Emily, E.N (2012) Applied Thematic Analysis, SAGE Publication, 212.

Haasen, C., Verthein, U. \& Degkwitz, P. (2007). Heroin-assisted treatment for opioid dependence. British Journal of Psychiatry, 191: 55-62.

Hanson, G., Venturelli, P.J. \& Fleckenstein, A.E. (2009). Drugs and Society, Jones and Bartlett: London.

Harrison, L.D., Backenheimer, M. \& Inciardi J. A. (1996). History of Drug Legislation.,University of Amsterdam: Netherlands. 
Hart, C., Ksir, C. \& Ray, O. (2008). Drugs, Society and Human Behaviour, twelfth edition, McGraw Hill Education: New York.

Henning, K.M.D. (2010). A Member's Perspective on the Geriatrics and Palliative Care Conference in Saudi Arabia. Retrieved from http://www.aahpm.org/apps/blog/?author=111

Hofstede, G. (1986). Cultural differences in teaching and learning. International Journal of Intercultural Relations, 10: 301-320

House, K.E. (2013). On Saudi Arabia: Its People, Past, Religion, Fault Lines - and Future, Knoff: New York.

Hulse, G.K., Morris, N., Arnold-Reed, D. \& Tait, R.J. (2009). Improving Clinical Outcomes in Treating Heroin Dependence: Randomized, Controlled Trial of Oral or Implant Naltrexone. Archives of General Psychiatry, 66(10): 1108-15, October. doi:10.1001/archgenpsychiatry.2009.130. PMID 19805701.

Inciardi, R. (2004). Drug Use: a Reference Handbook. ABC-Clio-Greenwood: USA.

INCSR (2010), Drug and chemical control, united state department of state, Bureau for international narcotics and law enforcements affairs Vol 1, 545 http://informahealthcare.com/doi/abs/10.3109/14659891.2011.606349.

Kaplan, GA, Haan, MN, \& Syme, S. (1987). Socio-economic status and health, in RW Amler \& HB Dull (Eds), Closing the Gap: The Burden of Unnecessary Illness, Oxford University Press; New York: 125-29.

Karam, EG, Mneimneh ZN, Karam An, Fayyad JA, Nasser., S, Chatterji., S Kessler Rc. (2008). Life time Prevalence of Mental Health Disorders: First Onset, Treatment and Exposure to War. PloS Medicine, 5(4): e61, 100-125, http://www.arabpsynet.com/Journals/ajp/AJP19.2Full.pdf

Karoub, J. (2010). Saudi rehab center studies oldest US addiction treatment, Saudi Gazette, retrieved from http://www.saudigazette.com.sa/index.cfm?method=home.regcon\&contentID= 2010053173951

King Faisal Specialist Hospital and Research Center (Jeddah, Saudi Arabia) (2013). Substance use disorders in Saudi Arabia: review article, Journal of Substance Use, 18(6): 450-66.

Latimer, W.W., Harwood, E.M., Newcomb, M.D. \& Wagenaar, A.C. (2003). Measuring public opinion on alcohol policy: a factor analytic study of a US probability sample. Addict Behav, 28: 301-13.

Lenton, S., Dietze, P.M., Degenhardt, L., Darke, S. \& Butler, T.G. (2009). Naloxone administration by peers in cases of heroin overdose. Medical Journal of Australia, 191 (8): 469.

Lowinson, J.H., Ruiz, Pedro, Millman, R.B. \& Langrod, J.G. (Eds) (2005). Substance Abuse: A Comprehensive Textbook (fourth edition). Lippincott Williams \& Wilkins: Philadelphia.

MacCoun, R. \& Reuter, P. (1997). Interpreting Dutch cannabis policy: Reasoning by analogy in the legalization debate. Science, 278: 47-51.

Marlatt, G.A. (2008). Harm Reduction: Pragmatic Strategies for Managing High Risk Behaviors, Guilford Press: New York.

Marlatt, G.A. \& Donovan, D.M. (2005). Relapse Prevention: Maintenance Strategies in the Treatment of Addictive Behaviora, Guildford Press New York.

Martin, E. (2006). The pharmaceutical person. Biosciences, 1:237-87. 
Merriam, S. (2009). Qualitative research: A guide to design and implementation. San Francisco, CA: Jossey-Bass.

Micheal T.W. (1998), Harm reduction. Retrieved from,http://www.thebody.com/content/art14023.html

Ministry of Health (1997). Annual report of the statistics department. Riyadh, Saudi Arabia.

Monte, C.F. (1995). Beneath the mask: An introduction to theories of personality, fifth edition, Harcourt Brace: New York.

National Opioid Pharmacotherapy Statistics Annual Data (2012). Drug Treatment Series, Number 16, Australian Institute of Health and Welfare [AIHW], Commonwealth of Australia, Canberra, Cat. no. HSE 122, http://www.ancd.org.au/Drugs -in-Australia/national-data.html

Nayyer, I. (2000). Substance dependence: A hospital based survey. Saudi Medical Journal, 21: 51-7.

NCADA (1995). Annual Report 1995. Ministry of Home Affairs, Singapore.

National Drug Strategy 2010-2015. Australian Government: Canberra (see Pillar 3, Harm Reduction) from http://www.nationaldrugstrategy.gov.au/internet/drugstrategy.

National Drug Strategic Framework (2003). Evaluation of the national drug strategic framework (NDSF) 1998-99 - 2003-04. [Author: Success Works p/1]. Retrieved from http://www.health.gov.au/internet/drugstrategy/publishing.

Opium Act (2009). Netherlands Government. WHO MiNDbank: More Inclusiveness Needed in Disability and Development, third edition, http://www.mindbank.info/item/2026

Osman, A. \& Shawoosh, M. (2003). Heroin addiction in Saudi Arabia - not merely a behavioural problem. Annals of Saudi Medicine, 23: 419-21.

Otto, J. (1992. Normalization of the drug problem: an outline of the Dutch drugs policy, retrieved from, http://www.druglibrary.org/schaffer/misc/nethnorm.htm

Pennington, D. (1999). An Overview of Drug Use and Drug Policy in Australia. Museum Victoria Lecture Series.

Reinarman, C. \& Levine, H.G. (2009). Crack in America: demon drugs and social justice, University of California Press.

Rice, S. (2012). "New hallucinogenic drug 25B-NBOMe and 25I-NBOMe led to South Australian man's bizarre death", Hemp Embassy. Retrieved from, http://www.news.com.au/national-news/south-australia/new-hallucinogenicdrug-25b-nbome-and-25i-nbome-led-to-south-australian-mans-bizarredeath/story-fndo4dzn-1226472672220\#ixzz2dyNT6FRx.

Robinson, S. \& Ustinoff, J. (Eds). (2012). The 1960s in Australia: People, Power and Politics, Cambridge Scholars Publishing: UK.

Roxburgh, A. \& Burns, L. (2009b). Drug related hospital stays in Australia 19932007. National Drug and Alcohol Research Centre, Department of Health and Aging, Sydney.

Sackville, R. (1979). Royal Commission into the Non-medical Use of Drugs. Adelaide, South Australia.

Schatz, E., Schiffer, K. \& Kools, J.P. (2011). The Dutch treatment and social support system for drug users. Recent developments and the example of Amsterdam. International Drug Policy Consortium, Amsterdam. 
Statistics of Drug Use in Australia (2006). Australian Institute of Health and Welfare Series 18. Canberra, published 2007.

Statistics on Drug Abuse in Australia, (1994). Commonwealth Department of Human Services and Health, Canberra.

Stoicescu, C. (Ed.) (2012). The Global State of Harm Reduction 2012: Towards an integrated response, Harm Reduction International: London.

Strauss, A. (1987). Qualitative analysis for social scientists. New York: Cambridge University Press.

United Nations Office on Drugs \& Crime (2008). Amphetamine and ecstasy. Retrieved from, http://www.unodc.org/documents/scientific/ATS/Global-ATSAssessment-2008-Web.pdf.

van der Laan, (2013). Coffee shops near schools to reduce business hours, retrieved from, http://www.amsterdam.info/coffee-shop-news/.

Van Laar, Margriet, et al., (2012). The Netherlands drug situation 2011: report to the EMCDDA by the Reitox National Focal Point. (Utrecht: Trimbos Institute, Netherlands Institute of Mental Health and Addiction) retrieved from, p. 40. http://www.trimbos.org/ /media/English\%20site/AF1130\%20The\%20Netherla nds... - See more at:

http://www.drugwarfacts.org/cms/The+Netherlands\#sthash.zU00KXfW.dpuf

Wessendorf, S. (2010). The multiculturalism backlash: European discourses, policies and practices, Taylor \& Francis: New York: 73-75, ISBN 978-0-41555649-1.

White, C. (2010). Ecstasy impurity leads to designer drug rise, retrieved from, www.abc.net.au/news/2011-05-09/ecstasy-impurity-leads-to-designer-drugrise/2705848.

Wodak, A., Dolan, K.A., Imrie, A. A., Gold, J., Wolk, J., Whyte, B.M. \& Cooper, D.A. (1987). Antibodies to human immunodeficiency virus in needles and syringes used by intravenous drug abusers. Medical Journal of Australia, 147: 275-6.

Wolf, J., Linssen, L. \& Graaf, I. (2003). Drug consumption facilities in the Netherlands. Journal of Drug Issues, 33(3): 649-661.

Yacoubian, G.S. (2007). Assessing the relationship between marijuana availability and marijuana use: A legal and sociological comparison between the United States and the Netherlands. Journal of Alcohol and Drug Education, 51(4): 1734. 